\title{
Voluntary feed intake, nitrogen and phosphorus losses in rainbow trout (Oncorhynchus mykiss) fed increasing dietary levels of soy protein concentrate
}

\author{
Françoise Médale ${ }^{\left(1^{*}\right)}$, Thierry Boujard ${ }^{(1)}$, Frédéric Vallée ${ }^{(1)}$, Denise Blanc ${ }^{(1)}$, \\ Muriel Mambrini ${ }^{(2)}$, Arjen Roem ${ }^{(3)}$, Sadasivam J. Kaushik ${ }^{(1)}$ \\ (1) Unité mixte Inra-Ifremer de nutrition des poissons, Station d'hydrobiologie Inra, \\ BP 3, 64310 Saint-Pée-sur-Nivelle, France. \\ (2) Laboratoire de génétique des poissons, Inra, 78352 Jouy-en-Josas cedex, France. \\ (3) Aquaculture Research Centre, Nutreco, Stavanger, Norway.
}

Received December 29, 1997; accepted April 8, 1998.

\begin{abstract}
High energy extruded diets were formulated to conlain the same level of protein supplied either by soy protein concentrate (SPC) or fish meal. Three experiments were performed in order to measure voluntary feed intake and feed waste, faecal losses and soluble losses of nitrogen and phosphorus in rainbow trout (average body weight: $100 \mathrm{~g}$ ). Voluntary feed intake and growth performance of fish fed with demand feeders were not different when diets contained 0,50 or $75 \%$ SPC instead of fish meal. Total replacement of fish meal by SPC led to a significant decrease in feed intake and resulted in poor growth. This was partly due to methionine deficiency in the SPC based diet. With the addition of crystalline DL methionine in the diets, an improvement of feed intake and growth performance was apparent. Protein digestibility was high, regardless of the protein source. Excretion of ammonia and urea increased with the level of SPC in the diet. Nitrogen losses decreased when methionine was added to the diet containing only SPC as a protein source. Availability of phosphorus increased with the level of SPC in the diets. Daily soluble losses were not affected by the dietary treatments but the pattern of phosphorus excretion after feed intake was modified. The rise in soluble phosphorus in water occurred later when fish were fed diets with soy protein whatever the dietary level of soy protein concentrate. (C) Ifremer/Elsevier, Paris
\end{abstract}

Digestibility / excretion / nitrogen / phosphorus / soy protein / voluntary feed intake / rainbow trout

Résumé - Effet de taux croissants de concentré protéique de soja dans le régime de la truite arc-en-ciel sur l'ingestion de nourriture et les rejets d'azote et de phosphore. L'objectif de l'étude était d'évaluer les effets du remplacement partiel ou total de la farine de poisson par du concentré protéique de soja sur la consommation volontaire de nourriture et les pertes fécales et métaboliques d'azote et de phosphore chez la truite arc-en-ciel (poids moyen : $100 \mathrm{~g}$ ). La consommation d'aliment et les performances de croissance des poissons nourris par des distributeurs d'aliment à la demande n'ont pas été affectées jusqu'à un taux de substitution de $75 \%$. Le remplacement total de la farine de poisson par le concentré protéique de soja a conduit à une faible croissance résultant d'une baisse significative de la consommation d'aliment. La supplémentation en DL-méthionine sous forme cristalline a permis d'améliorer les performances de croissance grâce à une augmentation de l'ingestion d'aliment. Lá digestibilité des protéintes était élevée pour tous les régimes, quelle que soit la source protéique. L'excrétion d'azote ammoniacal et d'azote uréique a augmenté avec le taux de concentré protéique de soja dans l'aliment. La supplémentation en méthionine de l'aliment contenant le concentré protéique de soja comme seule source de protéine a permis de réduire les pertes métaboliques d'azote. La disponibilité du phosphore a augmenté avec le taux de concentré protéique de soja de l'aliment. Le remplacement partiel ou total de la farine de poisson par le concentré protéique de suja ı'a pas affecté la quantité de phosphore soluble excrété par jour ; cn revanche, le profil postprandial d'excrétion a été modifié. (C) Ifremer/Elsevier, Paris

Digestibilité / excrétion / azote / phosphore / protéine de soja / ingestion volontaire / truite arc-en-ciel

* Corresponding author, e-mail: medale @st-pee.inra.fr 


\section{INTRODUCTION}

One of the major challenges in fish nutrition is to decrease the dietary amount of fish meal without impairment of production and water quality. One of the most promising alternatives to fish meal seems to be soybean which is rich in protein and generally low in phosphorus. Earlier studies with rainbow trout led to the conclusion that soybean protein could only be a partial substitute to fish meal $[24,26]$. However, the possibility of a total replacement of fish meal by soy protein concentrate (SPC) without negative effect on growth performance and flesh quality of rainbow trout was reported [12]. The difference between these results could be explained by the source of soy protein incorporated into the diets. Most soy products contain antinutritional factors [17] which could decrease both appetite and digestibility [15]. They also contain phytic phosphorus which is not highly available for most fish species [16]. Most of the antinutritional factors can be inactivated or reduced by proper processing treatments but the amounts of waste of nutritional origin arising from uneaten feed, undigested matter and end products of metabolism can vary with the quality of the soy product [25]. Since sustainable aquaculture is dependent upon minimal environmental loading, the effects of fish meal substitutes on waste production should be taken into consideration. The aim of this work was to study the effect of increasing dietary levels of a soy protein concentrate on feed, faecal and soluble losses in rainbow trout.

\section{MATERIAL AND METHODS}

\subsection{Experimental diets}

Six experimental diets, designated as $\mathrm{C}, 1,2,3,4$ and 5, were set up to contain a constant level of protein brought in through different proportions of soy protein concentrate (SPC DanPro) and fish meal (table I). All diets were prepared using a twin-screw extruder and post-extrusion coating of fats (ARC, Nutreco, Norway). The control diet $\mathrm{C}$ contained only Norwegian low temperature fish meal as a protein source. Diets 1 and 2 contained both fish meal and SPC as protein sources. In diets 3,4 and 5, fish meal was totally replaced by SPC. Diets 4 and 5 were supplemented by adding crystalline DL-methionine so that the level of methionine reached 0.8 and $1 \%$ of the dietary dry matter respectively, and was above the needs of rainbow trout [20]. An aliquot of each diet was sampled and analysed following the usual procedures: dry matter by drying in an oven at $110^{\circ} \mathrm{C}$ for $24 \mathrm{~h}$, ash by combustion in a furnace muffle at $550^{\circ} \mathrm{C}$ for $18 \mathrm{~h}$, crude protein by Kjeldahl method (total nitrogen $\times 6.25$ ) after acid digestion, lipid by extraction using petroleum ether in a Soxhlet apparatus after acid hydrolysis, energy using a Gallenkamp adiabatic calorimeter, phosphorus by spectrophotometric quantitation of phosphovanadomolybdates. Free methionine concentrations were measured using ion exchange chromatography after hydrolysis with $0.1 \mathrm{~N} \mathrm{HCl}\left(110^{\circ} \mathrm{C}, 24 \mathrm{~h}\right)$.

\subsection{Measurements of digestibility}

Faecal losses were measured through a study of digestibility by an indirect method. Digestibility trial was performed with duplicate groups of 10 fish (average body weight: $100 \mathrm{~g}$ ) fed twice a day the experimental diets containing yttrium $(0.1 \%)$ as an inert tracer. After a 30-day adaptation period, faeces were continuously collected over a 25 -day period using an automatic faeces collector with rotative grids [6]. Faeces were freeze dried before analysis which was performed as described above. Yttrium concentrations were determined by atomic absorption spectrophotometry. The apparent digestibility coefficients (ADC) of the dietary components were calculated as outlined by Kim and Kaushik [13].

Table I. Protein sources and chemical composition of the experimental diets.

\begin{tabular}{|c|c|c|c|c|c|c|}
\hline Diets & $\mathrm{C}$ & 1 & 2 & 3 & 4 & 5 \\
\hline \multicolumn{7}{|l|}{ Protein sources (\%) } \\
\hline Fish meal & 100 & 50 & 25 & 0 & 0 & 0 \\
\hline Soy protein concentrate & 0 & 50 & 75 & 100 & 100 & 100 \\
\hline \multicolumn{7}{|l|}{ Crystalline DL-methionine } \\
\hline $\mathrm{g} / 16 \mathrm{~g} \mathrm{~N}$ & 2.61 & 2.05 & 1.60 & 1.26 & 1.78 & 2.23 \\
\hline Chemical score & 1.30 & 1.01 & 0.80 & 0.63 & 0.89 & 1.12 \\
\hline \multicolumn{7}{|l|}{ Chemical composition } \\
\hline Protein (\% DM) & 39.3 & 39.8 & 42.0 & 41.9 & 42.2 & 41.7 \\
\hline Fat (\% DM) & 21.1 & 22.1 & 21.5 & 21.8 & 21.5 & 22.0 \\
\hline Gross energy $\left(\mathrm{kJ} \cdot \mathrm{g}^{-1} \mathrm{DM}\right)$ & 22.5 & 22.6 & 22.7 & 23.0 & 22.9 & 23.3 \\
\hline Ash (\% DM) & 10.7 & 9.1 & 8.5 & 7.6 & 7.7 & 7.6 \\
\hline Phosphorus (\% DM) & 1.9 & 1.9 & 1.8 & 1.6 & 1.6 & 1.3 \\
\hline
\end{tabular}

${ }^{1}$ Chemical score $=\mathrm{mg}$ limiting IAA in $1 \mathrm{~g}$ of protein/mg IAA required to meet the need in $1 \mathrm{~g}$ of protein $(2 \mathrm{~g} / 16 \mathrm{~g} \mathrm{~N})$; DM $=$ dry matter. 


\subsection{Measurements of voluntary feed intake}

Rainbow trout originating from the same parental stock were obtained from the Inra experimental fish farm (Donzacq, Landes, France). At the beginning of the trial, after having feed withheld for one day, 18 groups of 10 trouts were randomly distributed amongst 18 fiberglass tanks of $100 \mathrm{~L}$ each (initial stocking density $9.75 \mathrm{~kg} \cdot \mathrm{m}^{-3}$ ). An additional group of 5 trouts were killed by an overdose of ethylene glycolmonophenyl ether and stored at $-20^{\circ} \mathrm{C}$ for later estimation of the initial whole body composition. The tanks were part of two units of recirculating water of 12 tanks each. Each tank was equipped with a decan-ter, allowing a daily control of the amount of uneaten pellets. Water flow of each tank was $3 \mathrm{~L} \cdot \mathrm{min}^{-1}$, and a $1.5 \mathrm{~L} \cdot \mathrm{min}^{-1}$ input of tap water was allowed permanently in each of the recirculating units. Water temperature was electronically monitored and maintained at $16^{\circ} \mathrm{C}\left( \pm 0.2^{\circ} \mathrm{C}\right)$. The light/dark cycle was L/D $15.5 / 8.5$ ( $4 \mathrm{~W}$ bulbs switched on between $05: 30 \mathrm{~h}$ and 21:00 h).

Fish were fed on demand by means of electronic self-feeders (see [4] for description). This feeding system is designed in such a way that each time a fish activates a rod, an electric pulse is generated and, through a relay, triggers an electric feeder that delivers a predetermined amount of feed (between 0.3 and $0.5 \mathrm{~g}$ ). The rods were positioned $2 \mathrm{~cm}$ above the water surface in order to prevent any unintentional triggering of the feeders. Demands were rewarded only during two phases of $2.5 \mathrm{~h}$ per day each in order to make fish eat twice daily. Fish were conditioned to restrict their feeding activity to the restricted feeding time phases, by means of an additional $40 \mathrm{~W}$ light which was switched on only during feeding time (feeding time phases were 06:00-08:30 $\mathrm{h}$ and 18:00-20:30 h)

Each day of the trial, the feeders were monitored and a pre-weighed amount of feed was added if necessary. The uneaten pellets retained in the decanters were collected every day in order to evaluate the total amount of feed refusal. The watcr temperature, the nitrite concentration and the water flow were monitored.

At the end of the 33-day period of trial, feed was withheld for $24 \mathrm{~h}$, then fish were counted and weighed in groups in a pre-weighed bucket of water. Five trouts per group were killed by an overdose of ethylene glycol-monophenyl ether and stored at $-20^{\circ} \mathrm{C}$ for later estimation of the final whole body composition.

Voluntary intake and growth performance were calculated as follows:

Voluntary feed intake $(\mathrm{VFI})=$

dry feed intake/[(initial + final fish biomass)/2]

Digestible energy $(\mathrm{DE})$ intake $=$ gross energy $(\mathrm{GE})$ intake $\times \Lambda \mathrm{DC}$ of energy

Digestible protein (DP) intake $=$ crude protein (CP) intake $\times$ ADC of protein

Specific growth rate $($ SGR $)=$

$100 \times[\ln ($ final bio-mass $)-\ln ($ initial biomass $)] /$ number of days

\subsection{Measurements of soluble nitrogen and phosphorus losses}

Only diets C, 1, 3 and 5 were selected for measuring $\mathrm{N}$ and $\mathrm{P}$ excretion. Eight groups of 9 rainbow trouts (average individual body weight: $102 \mathrm{~g}$ ) were placed in tanks (water volume: $50 \mathrm{~L}$ ) of a recirculated water system with partial renewal $\left(10 \% \cdot \mathrm{d}^{-1}\right)$. A polystyrene cover was floating on the water surface of each tank in order to avoid gas exchange between water and air. Water flow rates were around $100 \mathrm{~L} \cdot \mathrm{h}^{-1}$ in each tank. Temperature was maintained at $17 \pm 0.5^{\circ} \mathrm{C}$ and daily photoperiod was L/D 13/11 (light on at $08: 30 \mathrm{~h}$ ).

Duplicate groups of fish were randomly assigned one of the four diets and adapted to the experimental conditions for 3 weeks prior to the measurements. During this adaptation period, they were fed twice a day (at 9:00 h and 16:00 h) near to satiation and the daily voluntary feed intake was measured. The lowest feed intake recorded was $1.3 \%$ of the biomass per day. This ration size was chosen to be distributed on the days of measurements.

Oxygen consumption and $\mathrm{N}$-ammonia, $\mathrm{N}$-urea, orthophosphate and carbon dioxide excretions of fish fed the fixed ration were measured during three 24-h periods. Water samples were collected each hour by an automatic system (see Médale et al. [19] for description) from tanks with fish (individual mean body weight: $110 \pm 7 \mathrm{~g}$ ) and from a tank without fish which served as a control. All sampling tubes were cleaned with $\mathrm{HCl}(0.5 \mathrm{M})$ and rinsed before the start of each 24-h period. Feed, offered as two equal rations between 9:00 h and 10:00 $\mathrm{h}$ and between 16:00 $\mathrm{h}$ and 17:00 h, was distributed through a hole in the cover. In order to ensure that water samples were collected from each tank at the same interval time after meals, feed was given according to a sequence. Water samples were continuously analysed for $\mathrm{N}$-urea and orthophosphate by colorimetric methods using an automatic analyser (ALPKEM). Concentrations of $\mathrm{N}$-ammonia, oxygen and carbon dioxide were measured using specific ionselective electrodes, each connected to a ionometer. A standard solution was also analysed each hour. The data were collected by a computer at the end of each sampling period. Hlow rates of water in fish tanks were recorded four times per cycle to control the stability.

Gas exchanges and phosphorus and nitrogen excretions of fish groups were calculated in relation to fish weight, water volume and flow rate according to Kaushik [9]. The amounts of digestible nitrogen, phosphorus or energy fed to the fish were estimated from the daily feed intake, the dietary composition and the respective ADC values.

\subsection{Statistical analysis}

The effects of the dietary treatments on the measured parameters were assessed by analysis of variance 
Table II. Apparent digestibility coefficients of dietary components and amounts of digestible components and energy supplied by the experimental diets. Data on the same line with the same superscript are not significantly different at the $5 \%$ level (ANOVA).

\begin{tabular}{lrrrrrr}
\hline Diets & $\mathrm{C}$ & 1 & 2 & 3 & 4 \\
\hline $\begin{array}{l}\text { Apparent digestibility coefficients (\%) } \\
\quad \text { Protein }\end{array}$ & $92.3^{\mathrm{a}}$ & $92.1^{\mathrm{a}}$ & $94.7^{\mathrm{a}}$ & $91.0^{\mathrm{a}}$ & $86.2^{\mathrm{a}}$ & $90.9^{\mathrm{a}}$ \\
$\quad$ Phosphorus & $28.7^{\mathrm{c}}$ & $37.4^{\mathrm{bc}}$ & $50.3^{\mathrm{ab}}$ & $51.8^{\mathrm{ab}}$ & $61.1^{\mathrm{a}}$ & $49.4^{\mathrm{ab}}$ \\
Digestible components & & & & & \\
$\quad$ Available phosphorus $\left(\mathrm{mg} \cdot \mathrm{g}^{-1} \mathrm{DM}\right)$ & 5.6 & 7.3 & 9.0 & 8.6 & 9.8 & 6.4 \\
$\quad$ Digestible energy $\left(\mathrm{kJ} \cdot \mathrm{g}^{-1} \mathrm{DM}\right)$ & 20.3 & 19.4 & 18.3 & 17.8 & 15.5 & 17.0 \\
Digestible protein $(\% \mathrm{DM})_{\text {DP/DE }\left(\mathrm{mg} \cdot \mathrm{kJ}^{-1}\right)}$ & 35.8 & 36.9 & 39.6 & 38.3 & 39.1 & 38.8 \\
\hline
\end{tabular}

${ }^{1} \mathrm{DP} / \mathrm{DE}=$ Digestible protein/Digestible energy.

(ANOVA) with the SAS package (SAS Inst. Inc., NC, USA). When $F$ values indicated significance, individual means were compared using the Duncan's multiple range test $(P<0.05)$.

\section{RESULTS}

\subsection{Faecal losses}

The ADC values of protein were high in all diets tested (table II). Protein digestibility was not affected either by the dietary protein source or by the DLmethionine supplement.

Phosphorus availability was significantly higher in diets containing SPC than in the control diet (table II) but the ADC of phosphorus contained in the fish meal diet was very low. Phosphorus availability was not significantly changed by the addition of DL-methionine to the diets.

\subsection{Voluntary feed intake}

No difference, either in voluntary feed intake (figure la), specific growth rate (figure lb), body composition or energy and protein retention (table III) could be detected between fish fed with diets $\mathrm{C}, 1$ and 2 , i.e. containing respectively 0,50 or $75 \%$ of SPC as a protein source, over the 33-day period of the trial. Fish fed the diet containing $100 \%$ of SPC showed a significant decrease in intake of dry matter and consequently of digestible protein and digestible energy. Growth and body composition were also affected, in comparison with fish fed the diets $\mathrm{C}, 1$ or 2. Nevertheless, this decrease in VFI and growth affected neither the amount of feed refusal nor the feed gain ratio. Energy and protein retention were not affected by the dietary protein sources.

The addition of DL-methionine had a significant effect on the feeding behaviour of the fish, with a significantly higher VHI in groups of fish fed diets 4 and 5 in comparison with the ones fed diet 3 (figure la). No differcnce could be detected in the VFI between the groups of fish fed with diets 4 and 5 , although they were supplemented with two different amounts of DLmethionine. However, these groups had a significantly lower VFI (approximately $25 \%$ ) than those fed diets C, 1 or 2.

\subsection{Soluble losses and nitrogen and phosphorus budgets}

Daily patterns of $\mathrm{N}$-ammonia excretion were little affected by dietary composition (figure 2). Maximum
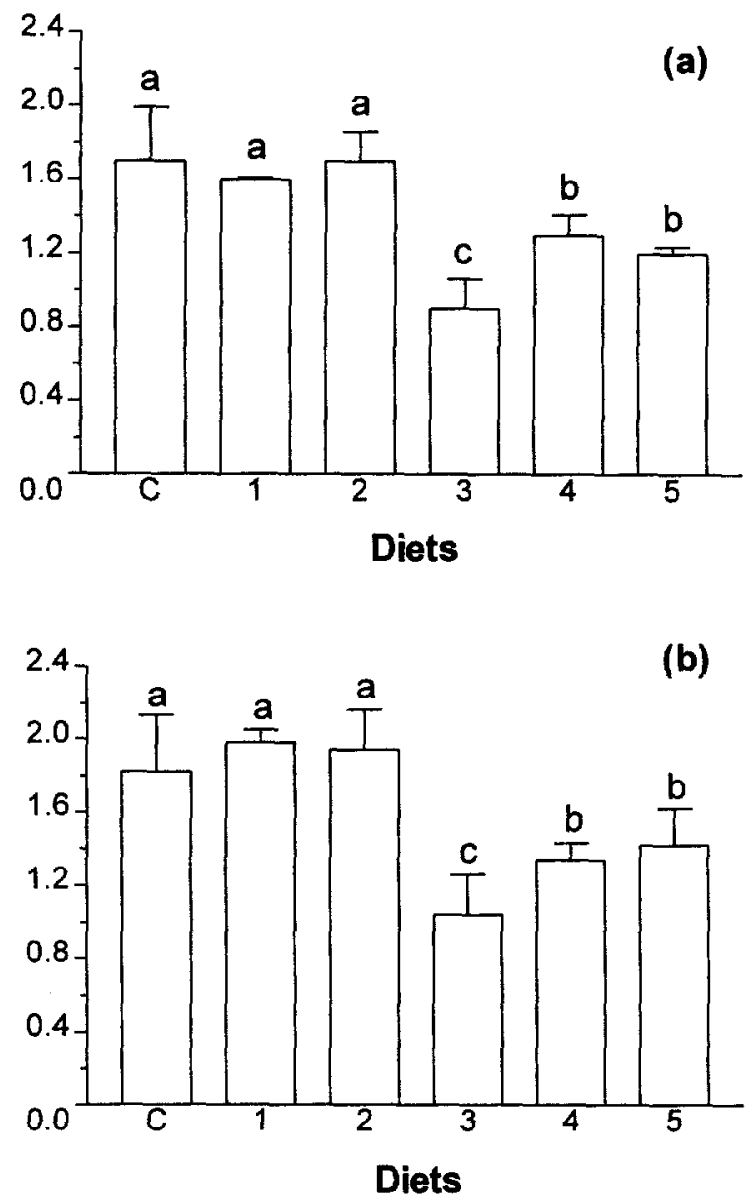

Figure 1. Voluntary feed intake (a) and specific growth rate (b) of the groups of fish fed with diets $C, 1,2,3,4$ and 5 during 33 days. Vertical bars indicate one standard deviation $(n=3)$.

Aquat. Living Resour. 11 (4) (1998) 
Table III. Final body composition, growth performance, feed intake and efficiency (mean \pm SD, 3 replicates per treatment, 10 fish/replicate) after 33 days. Initial body composition was: Dry matter $(\mathrm{DM})=21.26 \%$; Protein $=78.3 \%$; Fat $=4.5 \%$; Energy $=20.5 \mathrm{~kJ} \cdot \mathrm{g}^{-1} \mathrm{DM}$. Mortality was nil. Within each row, values with different superscript letters are significantly different $(P<0.05)$.

\begin{tabular}{|c|c|c|c|c|c|c|}
\hline Diets & $\mathrm{C}$ & 1 & 2 & 3 & 4 & 5 \\
\hline $\begin{array}{l}\text { Final body composition } \\
\text { Dry matter }(\%) \\
\text { Protein }(\% \mathrm{DM}) \\
\text { Fat }(\% \mathrm{DM}) \\
\text { Energy }\left(\mathrm{kJ} \cdot \mathrm{g}^{-1} \mathrm{DM}\right)\end{array}$ & $\begin{array}{l}25.3 \pm 1.3^{a} \\
59.5 \pm 5.3^{a} \\
26.1 \pm 5.9^{a} \\
24.6 \pm 1.1^{a}\end{array}$ & $\begin{array}{l}24.9 \pm 0.5^{\mathrm{a}} \\
59.5 \pm 1.1^{\mathrm{a}} \\
24.4 \pm 2.9^{\mathrm{a}} \\
24.6 \pm 0.5^{\mathrm{a}}\end{array}$ & $\begin{array}{l}23.7 \pm 1.6^{\mathrm{ab}} \\
62.0 \pm 5.1^{\mathrm{ab}} \\
23.3 \pm 2.4^{\mathrm{a}} \\
24.5 \pm 0.3^{\mathrm{a}}\end{array}$ & $\begin{array}{l}22.1 \pm 1.5^{\mathrm{ab}} \\
67.9 \pm 0.5^{\mathrm{b}} \\
14.0 \pm 2.7^{\mathrm{bc}} \\
22.8 \pm 0.3^{\mathrm{b}}\end{array}$ & $\begin{array}{l}21.3 \pm 0.7^{\mathrm{b}} \\
66.8 \pm 1.8^{\mathrm{ab}} \\
15.8 \pm 0.6^{\mathrm{b}} \\
23.2 \pm 0.1^{\mathrm{b}}\end{array}$ & $\begin{array}{l}21.4 \pm 1.2^{\mathrm{ab}} \\
69.1 \pm 1.5^{\mathrm{b}} \\
13.5 \pm 1.7^{\mathrm{c}} \\
22.9 \pm 0.4^{\mathrm{b}}\end{array}$ \\
\hline $\begin{array}{l}\text { Growth performance } \\
\text { Initial biomass }(\mathrm{g}) \\
\text { Final biomass }(\mathrm{g}) \\
\text { Feed gain ratio } \\
\text { Feed refusals }\end{array}$ & $\begin{aligned} 976 & \pm 4^{\mathrm{a}} \\
1792 & \pm 257^{\mathrm{a}} \\
0.97 & \pm 0.05^{\mathrm{a}} \\
1.75 & \pm 1.85^{\mathrm{a}}\end{aligned}$ & $\begin{aligned} 975 & \pm 3^{a} \\
1873 & \pm 49^{a} \\
0.86 & \pm 0.03^{a} \\
0.57 & \pm 0.90^{a}\end{aligned}$ & $\begin{array}{c}971 \pm 3^{\mathrm{a}} \\
1848 \pm 145^{\mathrm{a}} \\
0.90 \pm 0.02^{\mathrm{a}} \\
1.10 \pm 1.49^{\mathrm{a}}\end{array}$ & $\begin{array}{c}976 \pm 2^{\mathrm{a}} \\
1375 \pm 98^{\mathrm{c}} \\
0.92 \pm 0.20^{\mathrm{a}} \\
2.21 \pm 2.02^{\mathrm{a}}\end{array}$ & $\begin{array}{c}972 \pm 1^{\mathrm{a}} \\
1511 \pm 42^{\mathrm{b}} \\
0.96 \pm 0.06^{\mathrm{a}} \\
0.93 \pm 0.94^{\mathrm{a}}\end{array}$ & $\begin{array}{l}973 \pm 7^{a} \\
1559 \pm 98 \\
0.89 \pm 0.16^{a} \\
0.76 \pm 0.58^{a}\end{array}$ \\
\hline $\begin{array}{l}\text { Intake }\left(\mathrm{g} \text { or } \mathrm{kJ} \cdot \mathrm{kg}^{-1} \mathrm{BU}\right. \\
\text { Digestible energy } \\
\text { Digestible protein }\end{array}$ & $\begin{array}{l}339 \pm 58^{a} \\
6.1 \pm 1.1^{a}\end{array}$ & $\begin{array}{l}314 \pm 1^{\mathrm{a}} \\
6.0 \pm 0.1^{\mathrm{a}}\end{array}$ & $\begin{array}{r}315 \pm 30^{\mathrm{a}} \\
6.7 \pm 0.6^{\mathrm{a}}\end{array}$ & $\begin{array}{r}161 \pm 27^{\mathrm{b}} \\
3.5 \pm 0.6^{\mathrm{c}}\end{array}$ & $\begin{aligned} 174 & \pm 15^{b} \\
4.6 & \pm 0.4^{b c}\end{aligned}$ & $\begin{array}{l}185 \pm 6^{b} \\
4.6 \pm 0.2^{b}\end{array}$ \\
\hline $\begin{array}{l}\text { Retention ( } \% \text { of digesti } \\
\text { Energy } \\
\text { Protein }\end{array}$ & $\begin{array}{l}\text { ake) } \\
\begin{aligned} 51 \pm 7^{a} \\
47 \pm 6^{a}\end{aligned}\end{array}$ & $\begin{array}{l}55 \pm 1^{a} \\
49 \pm 4^{a}\end{array}$ & $\begin{array}{l}53 \pm 2^{a} \\
45 \pm 4^{a}\end{array}$ & $\begin{array}{l}55 \pm 13^{a} \\
50 \pm 12^{a}\end{array}$ & $\begin{array}{l}58 \pm 7^{a} \\
43 \pm 5^{a}\end{array}$ & $\begin{array}{l}55 \pm 13^{\mathrm{a}} \\
48 \pm 12^{\mathrm{a}}\end{array}$ \\
\hline
\end{tabular}

${ }^{1}$ Feed refusals are expressed as $\%$ of feed demands.

Table IV. Effect of experimental diets on nitrogen excretion, energy expenditure and protein utilization in rainbow trout. Within each row, values (means $\pm \mathrm{SD}, n=4)$ with different superscript letters are significantly different $(P<0.05)$.

\begin{tabular}{|c|c|c|c|c|}
\hline Diets & $\mathrm{C}$ & 1 & 3 & 5 \\
\hline Digestible $\mathrm{N}$ intake $\left(\mathrm{mg} \cdot \mathrm{kg}^{-1} \cdot \mathrm{d}^{-1}\right)$ & $705.9 \pm 5.5^{\circ}$ & $692.2 \pm 9.8^{d}$ & $770.2 \pm 20.5^{a}$ & $758.6 \pm 11.0^{b}$ \\
\hline $\begin{array}{l}\text { Ammonia-N excretion } \\
\mathrm{mg} \cdot \mathrm{kg}^{-1} \cdot \mathrm{d}^{-1} \\
\% \mathrm{~N} \mathrm{Dig}\end{array}$ & $\begin{array}{r}194.9 \pm 1.5^{\mathrm{d}} \\
27.6 \pm 0.1^{\mathrm{d}}\end{array}$ & $\begin{aligned} 239.1 & \pm 4.7^{\circ} \\
34.5 & \pm 0.4^{c}\end{aligned}$ & $\begin{aligned} 362.7 & \pm 7.1^{a} \\
47.1 & \pm 0.9^{a}\end{aligned}$ & $\begin{aligned} 306.8 & \pm 0.9^{b} \\
40.4 & \pm 0.5^{b}\end{aligned}$ \\
\hline $\begin{array}{l}\text { Urca-N excretion } \\
\mathrm{mg} \cdot \mathrm{kg}^{-1} \cdot \mathrm{d}^{-1} \\
\text { \% N Dig }\end{array}$ & $\begin{array}{r}30.3 \pm 1.3^{\mathrm{d}} \\
4.3 \pm 0.2^{\mathrm{d}}\end{array}$ & $\begin{array}{r}37.6 \pm 0.3^{c} \\
5.4 \pm 0.1^{\mathrm{c}}\end{array}$ & $\begin{array}{r}64.1 \pm 2.6^{\mathrm{a}} \\
8.3 \pm 0.2^{\mathrm{a}}\end{array}$ & $\begin{array}{r}52.8 \pm 1.0^{b} \\
7.0 \pm 0.1^{b}\end{array}$ \\
\hline Total Nitrogen excretion (\% N Dig) & $31.9 \pm 0.1^{\mathrm{d}}$ & $40.0 \pm 0.3^{\mathrm{c}}$ & $55.4 \pm 0.9^{a}$ & $47.4 \pm 0.6^{b}$ \\
\hline $\begin{array}{l}\text { Metabolic losses }\left(\mathrm{kJ} \cdot \mathrm{kg}^{-1} \cdot \mathrm{d}^{-1}\right) \\
\text { Total heat losses }\left(\mathrm{kJ}^{-} \mathrm{kg}^{-1} \cdot \mathrm{d}^{-1}\right)\end{array}$ & $\begin{array}{r}5.6 \pm 0.1^{\mathrm{d}} \\
68.8 \pm 0.4^{\mathrm{a}}\end{array}$ & $\begin{aligned} 6.9 & \pm 0.1^{\mathrm{c}} \\
69.0 & \pm 0.6^{\mathrm{a}}\end{aligned}$ & $\begin{array}{l}10.7 \pm 0.2^{\mathrm{a}} \\
69.8 \pm 1.6^{\mathrm{a}}\end{array}$ & $\begin{array}{r}9.0 \pm 0.1^{\mathrm{b}} \\
70.1 \pm 1.3^{\mathrm{a}}\end{array}$ \\
\hline Energy expenditure supplied by protein catabolism $(\%)$ & $36.3 \pm 0.5^{\mathrm{d}}$ & $44.5 \pm 0.6^{\mathrm{c}}$ & $67.8 \pm 0.5^{\mathrm{a}}$ & $56.9 \pm 1.0^{b}$ \\
\hline
\end{tabular}

values were attained 3-6 $\mathrm{h}$ after the morning meal, then $4-5 \mathrm{~h}$ after the evening meal. They were slightly delayed when fish were fed diets 3 and 5 containing $\mathrm{SPC}$ as the sole protein source. Daily excretion of both $\mathrm{N}$-ammonia and $\mathrm{N}$-urea were significantly affected by the experimental diets (table $I V$ ). Nitrogen release increased with the quantity of SPC in the diet. N-urea excretion was 15.6 to $17.7 \%$ of $\mathrm{N}$-ammonia excretion. Diet $\mathrm{C}$ which contained only fish meal as a protein source gave the lowest $\mathrm{N}$ excretion. The amount of excreted nitrogen represented only $32 \%$ of digestible nitrogen intake in fish fed the control diet. Nitrogen excretion was high when SPC was the sole dietary protein source without supplemental methionine (diet 3) but addition of methionine (diet 5) resulted in a significant decrease in nitrogen release (from 55 to $47 \%$ of digestible nitrogen intake).

Daily energy expenditure, as heat losses, was not affected by the experimental diets (table $I V$ ). The main effect of replacing fish meal by SPC on the energy budget was related to metabolic losses (increased amounts of dietary proteins being utilized to provide energy). As reported in table $I V$, the energy supplied by protein catabolism increased up to $67.8 \%$ with diet 3 and remained quite high with diet 5 .

Daily patterns of soluble $P$ excretion differed between fish fed the control diet and those fed the diets containing SPC. As shown in figure 3, soluble P excretion of fish fed diet $\mathrm{C}$ increased immediately after the morning meal while the highest values were recorded only $4 \mathrm{~h}$ after feeding in fish fed diets with SPC. This could result from a delay in digestion of the phosphorus brought by soybean. However this difference did not exist after the second meal. Daily soluble P excretion followed the same rhythm in all the fish fed diets containing SPC, irrespective of the dietary level of SPC. Despite such a difference in postprandial patterns of $\mathrm{P}$ excretion, the total amounts of soluble $\mathrm{P}$ excreted over a 24-h cycle were similar for the four dietary treatments (table $V$ ). Consequently, daily soluble phos- 


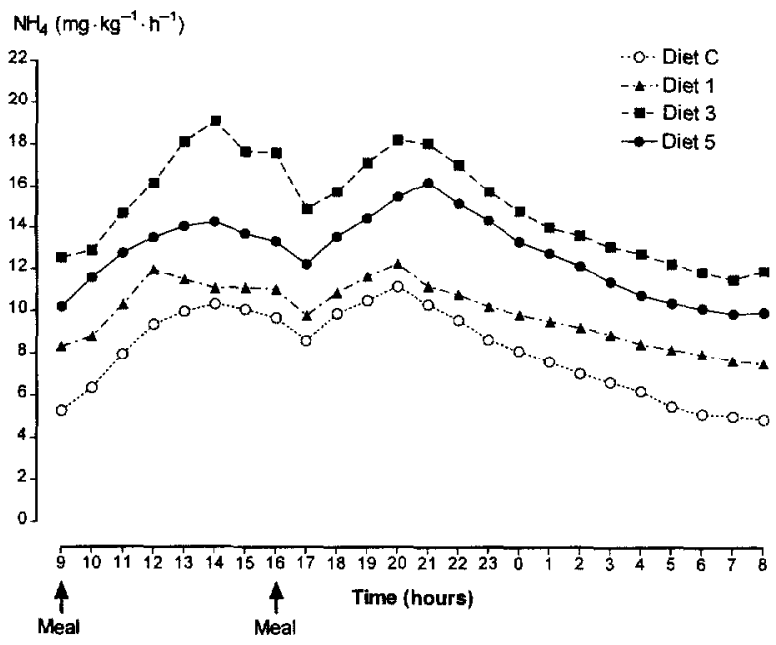

Figure 2. Postprandial patterns of $\mathrm{N}$-ammonia excretion in rainbow trout ted diets $\mathrm{C}, 1,3$ and $5(n=4)$.

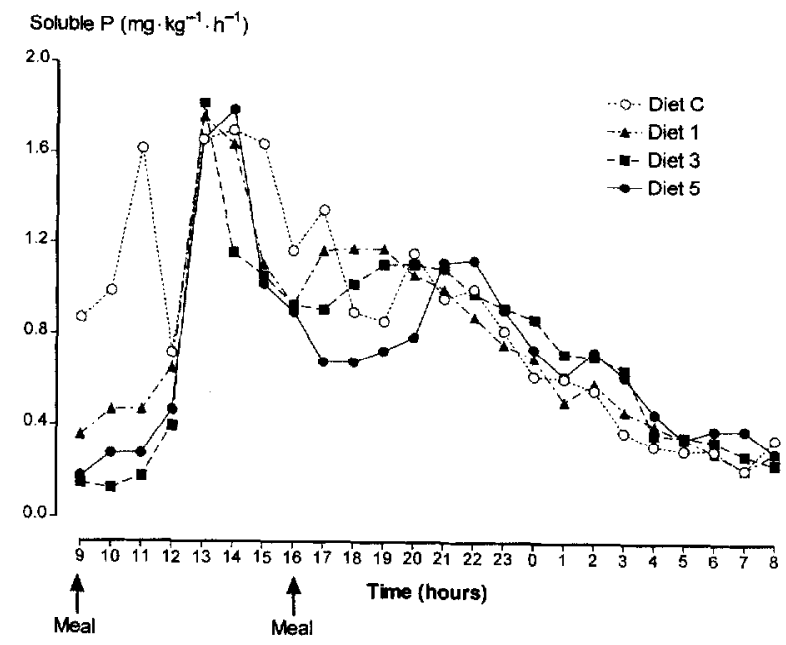

Figure 3. Postprandial patterns of soluble phosphorus excretion by rainbow trout fed diets $\mathrm{C}, 1,3$ and $5(n=4)$.

Table V. Effect of experimental diets on phosphorus budget in rainbow trout. Within each row, values (means \pm SD, $n=4$ ) with different superseript letters are significantly different $(P<0.05)$.

\begin{tabular}{|c|c|c|c|c|}
\hline Diets & C & 1 & 3 & 5 \\
\hline Phosphorus intake $\left(\mathrm{mg} \cdot \mathrm{kg}^{-1} \cdot \mathrm{d}^{-1}\right)$ & $278.9 \pm 2.2^{\mathrm{a}}$ & $206.4 \pm 2.9^{b}$ & $187.1 \pm 5.0^{\mathrm{c}}$ & $156.5 \pm 2.3^{d}$ \\
\hline Faecal losses $\left(\mathrm{mg} \cdot \mathrm{kg}^{-1} \cdot \mathrm{d}^{-1}\right)$ & $198.8 \pm 1.6^{\mathrm{a}}$ & $129.2 \pm 1.8^{b}$ & $90.2 \pm 2.4^{c}$ & $79.2 \pm 1.1^{\mathrm{d}}$ \\
\hline Digestible $\mathrm{P}$ intake $\left(\mathrm{mg} \cdot \mathrm{kg}^{-1} \cdot \mathrm{d}^{-1}\right)$ & $80.1 \pm 0.6^{\mathrm{b}}$ & $77.3 \pm 1.1^{\mathrm{c}}$ & $96.9 \pm 2.6^{\mathrm{a}}$ & $77.3 \pm 1.1^{\mathrm{c}}$ \\
\hline $\begin{array}{l}\text { Soluble losses } \\
\mathrm{mg} \mathrm{P} \cdot \mathrm{kg}^{-1} \cdot \mathrm{d}^{-1} \\
\text { Digestible P(\%) }\end{array}$ & $\begin{array}{l}23.6 \pm 2.9^{a} \\
29.5 \pm 3.8^{a}\end{array}$ & $\begin{array}{l}20.0 \pm 2.1^{a} \\
25.9 \pm 2.7^{a}\end{array}$ & $\begin{array}{l}21.7 \pm 4.8^{\mathrm{a}} \\
23.3 \pm 4.6^{\mathrm{a}}\end{array}$ & $\begin{array}{l}22.3 \pm 5.9^{\mathrm{a}} \\
28.9 \pm 7.8^{\mathrm{a}}\end{array}$ \\
\hline $\begin{array}{l}\text { Retention } \\
\text { Crude P intake }(\%) \\
\text { Available P intake }(\%)\end{array}$ & $\begin{array}{l}20.3 \pm 1.1^{\mathrm{d}} \\
70.5 \pm 3.8^{\mathrm{a}}\end{array}$ & $\begin{array}{l}27.7 \pm 1.0^{\circ} \\
74.1 \pm 2.7^{\mathrm{a}}\end{array}$ & $\begin{array}{l}40.2 \pm 2.4^{\mathrm{a}} \\
77.7 \pm 4.7^{\mathrm{a}}\end{array}$ & $\begin{array}{l}35.1 \pm 3.9^{b} \\
71.1 \pm 7.8^{a}\end{array}$ \\
\hline
\end{tabular}

phorus losses represented about $27 \%$ of the available phosphorus intake regardless of the diet.

\section{DISCUSSION}

It has been suggested that, in salmonids, protein digestibility is reduced when the diet contains high levels of antitrypsin factors $[14,15]$. In the present study, the level of anti-trypsin factor contained in the SPC was low $\left(0.32 \mathrm{mg} \cdot \mathrm{g}^{-1}\right)$ and the ADC values of protein supplicd by such a SPC werc high. This data confirms the efficiency of the technological treatments involved in removing trypsin inhibitors which brings the protein digestibility of SPC up to the level of that of fish meal.

Phosphorus availability was significantly higher in diets containing SPC than in the control diet. The ADC of phosphorus contained in the fish meal diet was lower than values previously reported for fish meal [16]. It is worth mentioning that LT-fish meal was used in this study and the diets were extruded. The high levels of phytic acid in soybean meal generally decrease the phosphorus availability in salmonids [22]. It seems that the concentration of phytic acid in the soy product we used was too low to affect the overall phosphorus digestion. Unfortunately, the level of phytic acid in the SPC was not measured. On the other hand, the total phosphorus content of the experimental diets was decreased by increasing proportions of SPC. This data agrees with Robert et al. [23] who found that the lower the dietary level of phosphorus, the higher its availability.

\subsection{Voluntary feed intake}

Replacing fish meal with up to $75 \%$ of SPC did not affect VFI or any production parameters when fish were fed on demand by means of self-feeders. It has already been demonstrated in previous experiments that fish are able to regulate their feed intake according to diet quality with a self-feeding device when the duration of feed availability is sufficiently long $[2,21]$.

The observed decrease in VFI in fish fed the diet containing $100 \%$ of SPC (diet 3 ) was not paralleled by an increase in feed refusal. Feed refusal was very low in all treatments, and did not show any decrease or increase with the passage of time (data not shown), 
regardless of diet. In a previous work, it was observed that feeds with poor acceptability were often rejected and caught again several times before being abandoned, and this feeding behaviour was responsible for increased feed waste [3]. Such increased feed waste was not recorded in our experiment, thus, the low amount of diet 3 demanded by trout seems not to be due to a low acceptability of SPC. Further, the negative effect of SPC on VFI can not only be explained by a methionine deficient diet, since the supplemented diet was not eaten at the same level as diets containing up to $75 \%$ of SPC. One might suggest that the high digestible protein/digestible energy (DP/DE) ratio of diets 4 and 5 (respectively 25 and $22 \mathrm{mg} \cdot \mathrm{kJ}^{-1}$, see table II) could be an additional explanation for this result. It could also be suspected that motivation for food, rather than acceptability of diet, was lowered by this protein source [8]. Unfortunately, in view of the current knowledge on appetite regulation in fish, it is difficult to speculate on the effect of such protein source on satiety and return of hunger.

\subsection{Soluble losses and nitrogen and phosphorus budgets}

Irrespective of the dietary treatments, the daily patterns of $\mathrm{N}$-ammonia excretion followed the rhythm generally described for teleosts in postprandial phase $[5,9,11]$. The rate of $\mathrm{N}$-ammonia excretion increased markedly after feeding, then slowly declined until the next meal.

While the daily patterns of $\mathrm{N}$-ammonia were similar for all groups, the amounts of both $\mathrm{N}$-ammonia and $\mathrm{N}$ urea excreted per day were significantly affected by the experimental diets. Nitrogen release increased with the quantity of SPC in the diet. The proportion of nitrogen excreted as $\mathrm{N}$-urea was of the same order as those previously reported for rainbow trout [19]. The diet C which contained only fish meal as protein source gave the lowest $\mathrm{N}$ excretion (32\% of digestible nitrogen intake). Nitrogen excretion was high (55\% of digestible nitrogen intake) when SPC was the sole dietary protein source without supplemental methionine (diet 3). In another trial, it has been shown that the activities of enzymes involved in amino acid oxidation were increased in the liver of fish fed SPC [18]. Addition of methionine (diet 5) resulted in a significant decrease in nitrogen excretion reflecting a reduction of amino acid oxidation. Amino acid imbalances generally lead to reduced rates of muscle protein synthesis [7]. The level of nitrogen excreted by fish fed diets with
SPC as the sole protein source could also be explained by the high DP/DE ratios of these diets compared to the control diet. The positive effect of high digestible energy level related to protein level in reducing nitrogen wastes has been clearly demonstrated $[10,19]$.

The main effect of replacing fish meal with SPC on the energy budget was related to metabolic losses, increased amount of dictary protcin bcing utilized to provide energy. However, as mentioned before, the positive effect of methionine supplementation might have been more marked if the diet had contained a higher level of digestible energy.

Daily patterns of soluble $P$ excretion differed between fish fed the control diet and those fed the diets containing SPC. Soluble P excretion after feed intake increased earlier in fish fed the diet $C$ than in fish fed diets with SPC, irrespective of the proportion of soy protein in the diets. This could result from a delay in digestion of the phosphorus brought by soy. However this difference did not exist after the second meal.

Despite such a difference in postprandial patterns of $P$ excretion, the total amounts of soluble $P$ excreted over a 24-h cycle were similar with the four dietary treatments. Published data on $\mathrm{P}$ excretion are very scarce. The present values ( 20 to $23.6 \mathrm{mg} \cdot \mathrm{kg}^{-1} \cdot \mathrm{d}^{-1}$ ) are lower than those obtained for seabass fed $1 \%$ live weight diets containing 11 to $16 \mathrm{mg} \mathrm{P} \cdot \mathrm{g}^{-1}$ dry matter [1]. The main interest of replacing fish meal with SPC was to decrease the total phosphorus release into the effluent due to the reduction of faecal phosphorus losses.

\section{CONCLUSION}

With respect to water quality, the total substitution of fish meal by a soy protein concentrate in high-fat extruded diets can not be recommended. The diets containing SPC as the sole protein source induced a decrease in VFI which lead to poor growth. However, up to $75 \%$ of fish meal can be replaced with protein concentrate without impairing feed intake, growth and feed utilization when fish are fed on demand by means of self-feeders. When fish are fed a fixed ration, total replacement of fish meal with SPC induced an increase in ammonia excretion which is partly reduced by adding crystalline DL-methionine to the diet. Retention of crude phosphorus was improved when the diet contained SPC. Consequently, a partial substitution of fish meal hy $50 \%$ SPC should thus have a positive effect on the environment.

\section{Acknowledgments}

The authors wish to thank P. Peyrotte for her technical assistance. This study was a part of an Eureka project 'Protein economy in fish feed by using soya'. 


\section{REFERENCES}

[1] Ballestrazzi R., Lanari D., D'Agaro E., Mion A., The effect of dietary protein level and source on growth, body composition, total ammonia and reactive phosphate excretion of growing seabass (Dicentrarchus labrax), Aquaculture 127 (1994) 197-206.

[2] Boujard T., Médale F., Regulation of voluntary feed intake in juvenile rainbow trout fed by hand or by selffeeders with diets containing two different protein/ energy ratios, Aquat. Living Resour. 7 (1994) 211-215.

[3] Boujard T., Le Gouvello R., Voluntary feed intake and discrimination of diets containing a novel fluoroquinolone in self-fed rainbow trout, Aquat. Living Resour. 10 (1997) 343-350.

[4] Boujard T., Dugy X., Genner D., Gosset C., Grig G., Description of a modular, low cost, eater meter for the study of feeding behavior and food-preferences in fish, Physiol. Behav. 52 (1992) 1101-1106.

[5] Brett J.R., Zala C.A., Daily patterns of nitrogen excretion and oxygen consumption of sockeye salmon (Oncorhynchus nerka) under controlled conditions, J. Fish. Res. Board Can. 32 (1975) 2479-2486.

[6] Choubert G., De la Noüe J., Luquet P., Digestibility in fish: improved device for automatic collection of feces, Aquaculture 29 (1982) 185-189.

[7] Cowey C.B., Walton M.J., Intermediary metabolism, in: Halver J.E. (Ed.), Fish nutrition, Academic Press, New York, 1989, pp. 259-329.

[8] Forbes J.M., Voluntary food intake and diet selection in farm animals. Centre for Agriculture and Biosciences International, Wallingford, UK, 1995, 532 p.

[9] Kaushik S.J., Influence of the nutrient status on the daily patterns of nitrogen excretion in the carp (Cyprinus carpio) and the rainbow trout (Salmo gairdneri), Reprod. Nutr. Dev. 20 (1980) 1751-1765.

[10] Kaushik S.J., de Oliva Teles A., Effects of digestible energy on nitrogen and energy balance in rainbow trout, Aquaculture 50 (1985) 89-101.

[11] Kaushik S.J., Cowey C., Dietary factors affecting nitrogen excretion by fish, in: Cowey C.B., Cho C.Y. (Eds.), Nutritional strategies and aquaculture waste, University of Guelph, Guelph, Ontario, Canada, 1991, pp. 3-19.

[12] Kaushik S.J., Cravedi J.P., Lalles J.P., Sumpter J., Fauconneau B., Laroche M., Partial or total replacement of fish meal by soybean protein on growth, protein utilization, potential estrogenic or antigenic effects, cholesterolemia and flesh quality in rainbow trout, Oncorhynchus mykiss, Aquaculture 133 (1995) 257274.

[13] Kim J.D., Kaushik S.J., Contribution of digestible energy from carbohydrates and estimation of protein/ energy requirements for growth of rainbow trout (Oncorhynchus mykiss), Aquaculture 106 (1992) 161-169.

[14] Krogdahl A., Holm H., Pancreatic proteases from man, trout, rat, pig, cow, chicken, mink and fox enzyme activities and inhibition by soybean and lima bean pro- tease inhibitors, Comp. Biochem. Physiol. 74B (1983) 403-409.

[15] Krogdahl A., Lea T.B., Olli J.L., Soybean proteinase inhibitors affect intestinal trypsin activities and amino acid digestibilities in rainbow trout (Oncorhynchus mykiss), Comp. Biochem. Physiol. 107A (1994) 215219.

[16] Lall S.P., Digestibility, metabolism and excretion of dietary phosphorus in fish, in: Cowey C.B., Cho C.Y. (Eds.), Nutritional strategies and aquaculture waste, University of Guelph, Guelph, Ontario, Canada, 1991, pp. 21-36.

[17] Liener I.E., Antinutritional factors in legume seeds: State of the art, in: Huisman J., van der Poel T.F.B., Liener I.E. (Eds.), Recent advances of research in antinutritional factors in legume seeds, Pudoc, Wageningen, 1989, pp. 6-14.

[18] Mambrini M., Vachot C., Kaushik S.J., Effet de l'emploi de concentré protéique de soja sur l'activité des enzymes de transamination chez la truite arc-en-ciel, Nutr. Clin. Métabol. 11 (1997) 342.

[19] Médale F., Brauge C., Vallée F., Kaushik S.J., Effects of dietary protein/energy ratio, ration size, dietary energy source and water temperature on nitrogen excretion in rainbow trout, Water Sci. Technol. 31 (1995) 185-194.

[20] National Research Council, Nutrient requirements of fish, National Academy Press, Washington DC, 1993, $114 \mathrm{p}$.

[21] Paspatis M., Boujard T., A comparative study of automatic feeding and self-feeding in juvenile Atlantic salmon (Salmo salar) fed diets of different energy levels, Aquaculture 145 (1996) 245-257.

[22] Richardson N.L., Higgs D.A., Beames R.M., McBride J.R., Influence of dietary calcium, zinc and sodium phytate level on cataract incidence, growth and histopathology in juvenile chinook salmon (Oncorhynchus tshawytscha), J. Nutr. 115 (1985) 553-567.

[23] Robert N., Le Gouvello R., Mauviot J.C., Arroyo F., Aguirre P., Kaushik S.J., Use of extruded diets in intensive trout culture: effects of protein to energy ratios on growth, nutrient utilization and on flesh and water quality, in: Kaushik S.J., Luquet P. (Eds.), Fish nutrition in practice, Inra, Paris, 1993, pp. 497-500.

[24] Rumsey G.L., Hughes S.G., Winfree R.A., Chemical and nutritional evaluation of soya protein preparations as primary nitrogen sources for rainbow trout (Oncorhynchus mykiss), Anim. Feed Sci. Technol. 40 (1993) $135-151$.

[25] Shimeno S., Kanetaka Y., Ruchimat T., Ukawa M., Nutritional evaluation of several soy proteins for fingerling yellowtail, Nippon Suisan Gakkaishi 61 (1995) 919-926.

[26] Tacon A.G.J., Haastler J.V., Featherstone P.B., Kerr K., Jackson A.J., Studies on the utilization of full fat soybean and solvent extracted soybean in a complete diet for rainbow trout, Bull. Jpn. Soc. Sci. Fish. 49 (1983) 1437-1443. 